\title{
Mutagenesis of Trichoderma reesei endoglucanase I: impact of expression host on activity and stability at elevated temperatures
}

Harshal A Chokhawala ${ }^{1,2}$, Christine M Roche ${ }^{1,2}$, Tae-Wan Kim ${ }^{1}$, Meera E Atreya ${ }^{1,4}$, Neeraja Vegesna ${ }^{3}$, Craig M Dana ${ }^{1,2}$, Harvey W Blanch ${ }^{1,2^{*}}$ and Douglas S Clark ${ }^{1,2^{*}}$

\begin{abstract}
Background: Trichoderma reesei is a key cellulase source for economically saccharifying cellulosic biomass for the production of biofuels. Lignocellulose hydrolysis at temperatures above the optimum temperature of $T$. reesei cellulases $\left(\sim 50^{\circ} \mathrm{C}\right)$ could provide many significant advantages, including reduced viscosity at high-solids loadings, lower risk of microbial contamination during saccharification, greater compatibility with high-temperature biomass pretreatment, and faster rates of hydrolysis. These potential advantages motivate efforts to engineer $T$. reesei cellulases that can hydrolyze lignocellulose at temperatures ranging from $60-70^{\circ} \mathrm{C}$.
\end{abstract}

Results: A B-factor guided approach for improving thermostability was used to engineer variants of endoglucanase I (Cel7B) from $T$. reesei $(\mathrm{TrEGI})$ that are able to hydrolyze cellulosic substrates more rapidly than the recombinant wild-type TrEGl at temperatures ranging from $50-70^{\circ} \mathrm{C}$. When expressed in T. reesei, TrEGl variant G230A/D113S/D115T (G230A/D113S/D115T Tr_TrEGl) had a higher apparent melting temperature $\left(3^{\circ} \mathrm{C}\right.$ increase in $\left.\mathrm{T}_{\mathrm{m}}\right)$ and improved half-life at $60^{\circ} \mathrm{C}\left(\mathrm{t}_{1 / 2}=161 \mathrm{hr}\right)$ than the recombinant ( $T$. reesei host) wild-type $\operatorname{TrEGl}\left(\mathrm{t}_{1 / 2}=74 \mathrm{hr}\right.$ at $60^{\circ} \mathrm{C}$, $\operatorname{Tr}$ _ $\left.T r E G I\right)$. Furthermore, G230A/D113S/D115T Tr_TrEGl showed 2-fold improved activity compared to Tr_TrEGl at $65^{\circ} \mathrm{C}$ on solid cellulosic substrates, and was as efficient in hydrolyzing cellulose at $60^{\circ} \mathrm{C}$ as $\operatorname{Tr} \_\operatorname{TrEGI}$ was at $50^{\circ} \mathrm{C}$. The activities and stabilities of the recombinant TrEGl enzymes followed similar trends but differed significantly in magnitude depending on the expression host (Escherichia coli cell-free, Saccharomyces cerevisiae, Neurospora crassa, or T. reesei). Compared to N.crassa-expressed TrEGI, S. cerevisiae-expressed TrEGI showed inferior activity and stability, which was attributed to the lack of cyclization of the N-terminal glutamine in Sc_TrEGl and not to differences in glycosylation. N-terminal pyroglutamate formation in TrEGl expressed in S. cerevisiae was found to be essential in elevating its activity and stability to levels similar to the T. reesei or N. crassa-expressed enzyme, highlighting the importance of this ubiquitous modification in GH7 enzymes.

Conclusion: Structure-guided evolution of T. reesei EGI was used to engineer enzymes with increased thermal stability and activity on solid cellulosic substrates. Production of TrEGl enzymes in four hosts highlighted the impact of the expression host and the role of N-terminal pyroglutamate formation on the activity and stability of TrEGl enzymes.

Keywords: Trichoderma reesei, Endoglucanase I, B-factor, Cellulase, Thermostability, Cell-free synthesis, Saccharomyces cerevisiae, Neurospora crassa, Pyroglutamate, Glutaminyl cylcase

\footnotetext{
* Correspondence: blanch@berkeley.edu; clark@berkeley.edu

${ }^{1}$ Energy Biosciences Institute, University of California, Berkeley, CA 94720, USA

${ }^{2}$ Department of Chemical and Biomolecular Engineering, University of

California, Berkeley, CA 94720, USA

Full list of author information is available at the end of the article
} 


\section{Background}

Efficient saccharification of cellulosic biomass to fermentable sugars is necessary for economical production of second generation biofuels. Several enzymes (exoglucanases, endoglucanases, oxidative enzymes, and $\beta$-glucosidases) act in concert to hydrolyze cellulose to glucose. The industrially employed filamentous fungus Trichoderma reesei has been evolved for cellulase production and is capable of secreting large quantities of cellulolytic enzymes at a relatively low cost [1,2]. These include two exoglucanases, Cel7A and Cel6A (CBH I and CBH II), which represent 50\% and 20\% of the total cellulase content, respectively, four endoglucanases, Cel7B (EGI), Cel5A (EGII), Cel12A (EGIII), and Cel45A (EGV) that represent approximately 15\%, 10\%, 1\%, and $<1 \%$ of the total cellulase content, respectively, and several lytic polysaccharide monooxygenases [3,4].

Lignocellulose hydrolysis at relatively high temperatures (above $50^{\circ} \mathrm{C}$, which is near the optimum for many fungal cellulases) may offer potential advantages, including reduced solution viscosity at high-solids loadings (>20 wt\%), lower risk of microbial contamination during saccharification, greater compatibility with high-temperature pretreatments, and potentially faster rates of hydrolysis [5]. The short halflives of $T$. reesei cellulases at temperatures above $50^{\circ} \mathrm{C}$, together with very low expression levels of thermophilic cellulases (typically less than $100 \mathrm{mg} / \mathrm{L}$, compared to over 150 gm/L for $T$. reesei cellulases) [6], motivates the development of thermostable $T$. reesei cellulases that can hydrolyze lignocellulose efficiently at temperatures beyond $50^{\circ} \mathrm{C}$. T. reesei endoglucanase I (TrEGI) is known to randomly cleave internal cellulosic bonds, thereby creating shorter cellulosic chains. Recent studies on optimizing the components of cellulase systems have underscored the importance of having TrEGI comprise a high fraction of the cellulase mixture (25-35\%) in order to efficiently hydrolyze pretreated lignocellulosic biomass $[7,8]$.

TrEGI has a bimodular structure with a 375-amino-acid (aa) catalytic domain (CD, Figure 1) attached to a 35-aa carbohydrate-binding module $(\mathrm{CBM})$ via a 26-aa linker. TrEGI has 11 disulfide bonds ( 8 in the $C D$ [highlighted in blue in Figure 1] and 3 in the CBM), $6 \mathrm{~N}$-glycosylation sites in the CD (highlighted in magenta in Figure 1), and a linker region rich in serine and threonine that are potential $\mathrm{O}$ glycosylation sites. It was selected for engineering enhanced thermostability because of its importance in cellulose hydrolysis and the availability of its crystal structure [9].

Although protein engineering has been used to improve the thermostability of numerous cellulases [10-13], there are no reports on improving the thermostability or increasing the optimal temperature of TrEGI. In this study, we employed a B-factor guided approach [14] to engineer thermostable variants of TrEGI using E. coli cell-free protein synthesis due its ease and throughput (Figure 2). Many thermostable mutants of TrEGI identified using

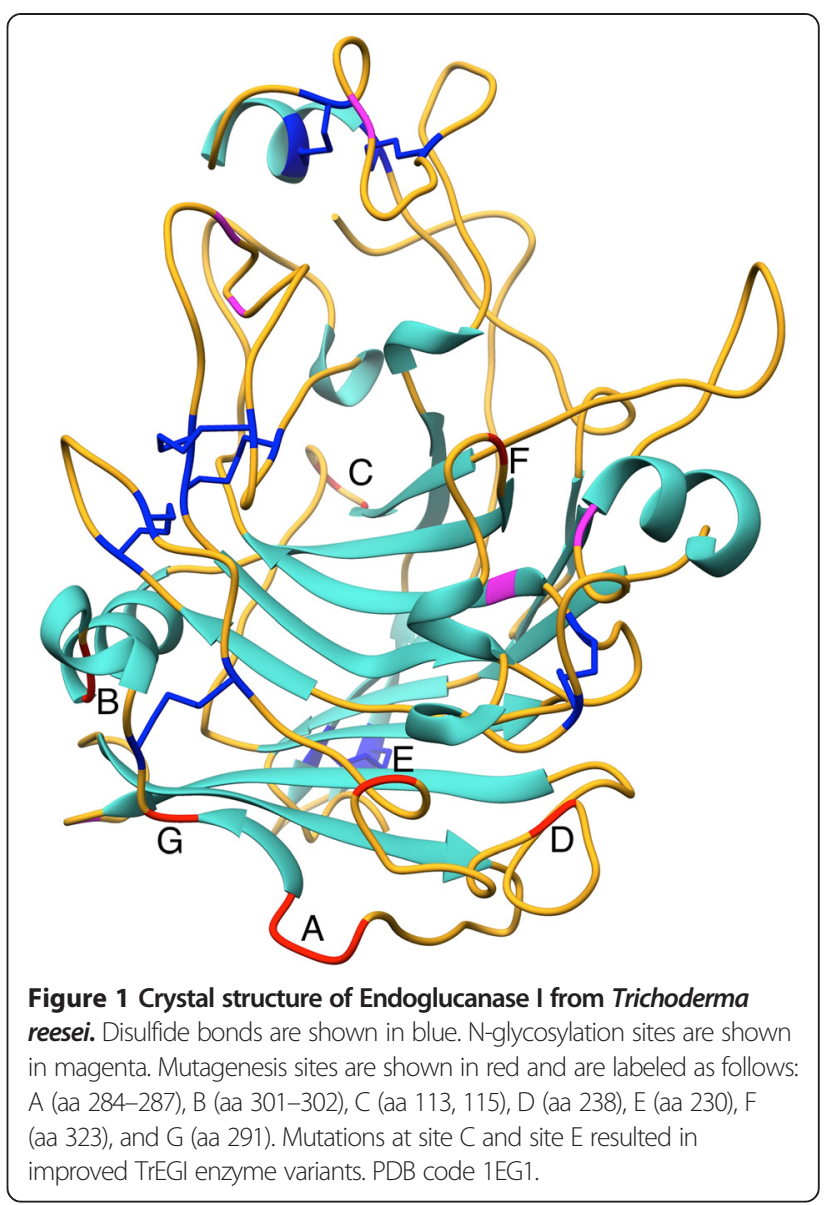

cell-free protein synthesis were subsequently expressed in the fungal hosts $S$. cerevisiae, $N$. crassa, and $T$. reesei to better mimic the properties of the native TrEGI enzyme in terms of folding and glycosylation (Figure 2). TrEGI variants, particularly G230A/D113S/D115T, were more stable compared to their recombinant wild-type versions when both the variant and wild-type were expressed in S. cerevisiae, $N$. crassa, or $T$. reesei, indicating that the positive influence of these mutations on stability translates across different expression hosts. However, the S. cerevisiaeexpressed enzymes were inferior in terms of activity and stability compared to the same enzymes expressed in $T$. reesei or $N$. crassa, which we attribute to the lack of cyclization of the N-terminal glutamine of TrEG1 expressed in our S. cerevisiae system.

\section{Results and discussion}

\section{B-factor guided mutagenesis}

Our efforts to improve the thermostability of TrEGI entailed a B-factor guided approach (B-FIT method) [14]. The Bfactor is a measure of the average deviation of a given residue from its mean position in the crystal structure. Residues having the highest average B-factors (obtained from the crystal structure) correspond to the most flexible sites in the 


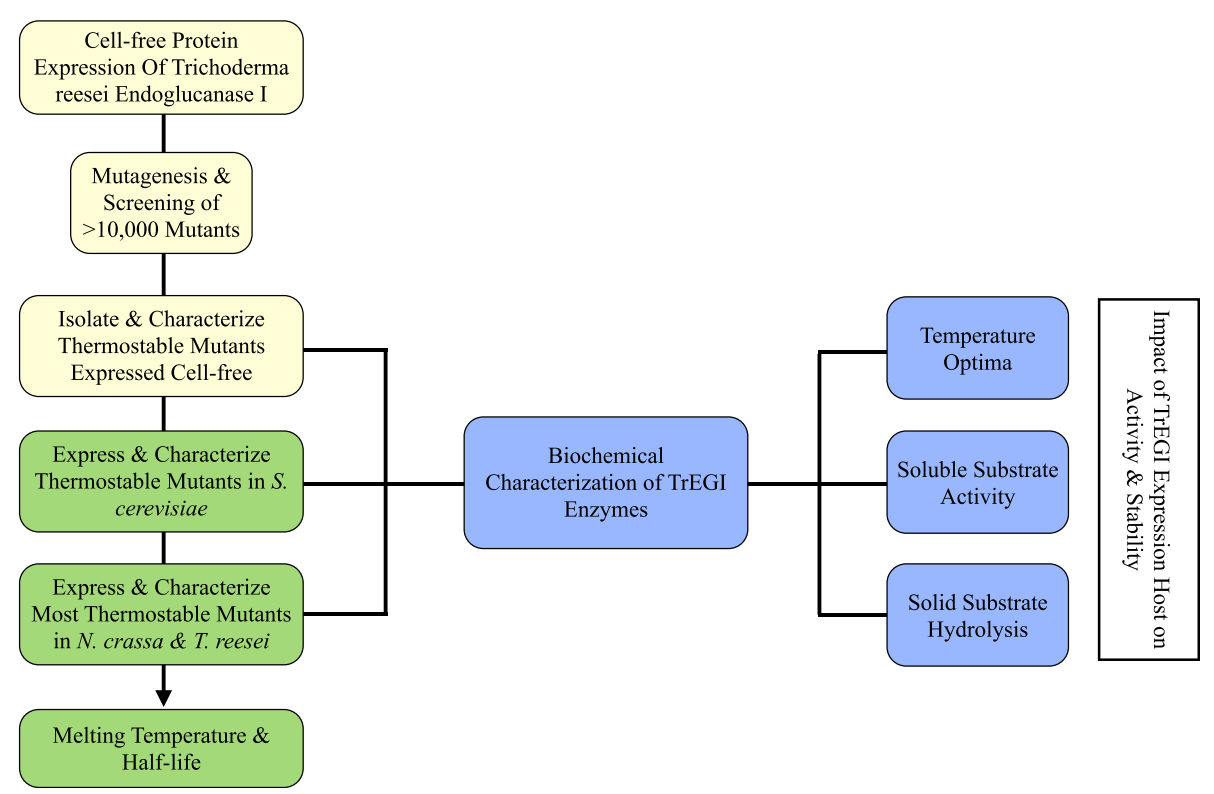

Figure 2 Engineering thermostable Endoglucanase I from Trichoderma reesei.

protein and provide targets for mutagenesis to improve thermostability. This strategy is based on the premise that the thermostability of a mesophilic enzyme can be enhanced by increasing its rigidity at the most flexible sites in its structure. Examples of B-factor guided mutagenesis to increase thermostability include a Bacillus subtilis lipase $\left(\Delta T_{50}^{60}\right.$ of $\left.42^{\circ} \mathrm{C}\right)$ [14] and a Pseudomonas fluorescens esterase $\left(\Delta T_{50}^{60}\right.$ of $9^{\circ} \mathrm{C}$ ) [15], where $\Delta T_{50}^{60}$ corresponds to the change in temperature at which the enzyme loses half its activity after an hour of incubation.

Using the crystal structure of the TrEGI catalytic domain (Figure 1), we identified the 20 amino acids with the highest B-factors. These amino acids were grouped in seven sites (Figure 1, in red) comprising one or more amino acids [Site A (aa 284-287), Site B (aa 301-302), Site C (aa 113, 115), Site D (aa 238), Site E (aa 230), Site F (aa 323), Site G (aa 291)], and were chosen for sitesaturation mutagenesis. Amino acids with high Bfactors that were in close proximity to the $\mathrm{N}$ - or Cterminus, disulfide bridges, or $\mathrm{N}$-glycosylation sites in the TrEGI crystal structure were not selected because they could interfere with disulfide-bond formation or lead to false positives due to compensation for nonglycosylation in a bacterial expression system.

A modification of the cell-free protein synthesis protocol developed in our laboratory [16] was used to express TrEGI in an active, soluble form (Additional file 1: Figure S1). The stability of the cell-free expressed TrEGI is comparable to TrEGI expressed in E. coli [17], but is considerably reduced compared to the native enzyme expressed in T. reesei [18]. Although cell-free protein synthesis yielded an inferior TrEGI enzyme, we proceeded to use cell-free expression as a tool to rapidly screen mutants of TrEGI, with the assumption that the effect of mutations imparting thermostability will be conserved upon expression in fungal hosts such as $T$. reesei.

The protocol for screening and selection of mutant TrEGI enzymes is shown in (Additional file 1: Figure S2). Mutagenesis and screening of 11,000 mutants at sites A-G generated $\sim 500$ mutants with higher activity toward carboxymethyl cellulose (CMC) after pre-incubation at $50^{\circ} \mathrm{C}$ for $45 \mathrm{~min}$ than the wild-type TrEGI expressed using cell-free synthesis. Sequencing the 70 mutants that showed highest activities after the heat treatment revealed that all but six mutants had a mutation at site E (amino acid 230, glycine). Alanine, arginine, serine, threonine, leucine, lysine, glutamic acid, glutamine, and methionine substitutions at this position all imparted improved thermostability. In addition, we found mutations at site C (amino acids D113, D115) that gave rise to more stable variants of TrEGI. Amino acid changes at this site for these TrEGI mutants were D113S/D113T and D115L/D115G. Even though the D113L/D115G mutant had greater thermostability at $50^{\circ} \mathrm{C}$, it was not pursued further because it had low specific activity relative to wild-type TrEGI expressed using cell-free synthesis. Since the single mutants (D113S, and D115T) were not isolated during the screening process that covered $>95 \%$ of all possible amino acid combinations at site C [19], it is highly likely that mutations at both these sites need to be present simultaneously to afford increased stability. 
Activity measurements of round I variants with improved thermostability

The activities of some of these thermostable TrEGI mutants toward $\mathrm{CMC}$, based on the amount of reducing sugar released before and after exposure to $50^{\circ} \mathrm{C}$ for various times, are summarized in Figure 3. Combining mutations at G230 with mutations at sites D113 and D115 resulted in triple mutant enzymes (G230X/D113S/D115T, X=K, A, S, R, E, $\mathrm{L}, \mathrm{T}, \mathrm{M}$; Figure 3) that were more active at $50^{\circ} \mathrm{C}$ than either of the engineered parents (Figure 3). All the triple mutants showed higher specific activity at $50^{\circ} \mathrm{C}$ on CMC compared to the wild-type TrEGI expressed using cell-free synthesis at $50^{\circ} \mathrm{C}$; mutants G230K/D113S/D115T and G230T/D113S/ D115T exhibited $\sim 5$ fold improvement in specific activity.

The engineered TrEGI enzymes also showed higher activity on solid substrates: Avicel and ionic-liquid pretreated Avicel (IL-Avicel) (Additional file 1: Figure S3). All of the engineered enzymes showed $\sim 2$-fold higher activity for Avicel hydrolysis (Additional file 1: Figure S3A) and $\sim 5$-fold improvement for IL-Avicel hydrolysis (Additional file 1: Figure S3B, G230X/D113S/D115T, X $=\mathrm{K}, \mathrm{A}, \mathrm{S}, \mathrm{R})$ at $50^{\circ} \mathrm{C}$ relative to the wild-type TrEGI expressed by cell-free synthesis. Many of these TrEGI mutants were active against both substrates at $55^{\circ} \mathrm{C}$, conditions under which the wildtype TrEGI expressed by cell-free synthesis was essentially inactive.

\section{Characterization of Trichoderma reesei endoglucanase I variants expressed in S. cerevisiae}

Considering the impact of proper folding and glycosylation on the stability, activity, and structure of proteins
[20-24], we sought to express TrEGI enzymes in a fungal host. Because recombinant expression of proteins in filamentous fungi is typically tedious, time-consuming, and not amenable to high-throughput, we used $S$. cerevisiae [25] as an intermediate fungal expression host to evaluate the stability and activity of the engineered TrEGI triple mutants (enzymes expressed in S. cerevisiae are designated Sc_TrEGI). Of all the triple mutants tested (G230X/D113S/D115T, X = K, A, S, R, E, L, T, $\mathrm{M})$, only five of the TrEGI mutants were expressed in active and soluble forms (G230X/D113S/D115T, X = A, $\mathrm{E}, \mathrm{R}, \mathrm{L}, \mathrm{T})$. The enzymes were secreted from yeast in a hyperglycosylated state (MW of 70-200 KDa) as observed previously [26,27], and thus were treated with an endoglycosidase (PNGase F) that cleaves N-glycans, reducing the molecular weight to 54-56 kDa (TrEGI MW is $46 \mathrm{kDa}$ based on aa sequence, with glycans contributing 8-10 kDa), which nearly matches the molecular weight of the natively-expressed TrEGI enzyme (50$55 \mathrm{kDa})$ [26].

Many of these TrEGI mutants exhibited higher hydrolytic activities on soluble (MU-cellobiose) and solid substrates (Avicel and IL-Avicel) compared to Sc_TrEGI (Additional file 1: Figure S4) at $50-65^{\circ} \mathrm{C}$. The mutant G230A/D113S/D115T Sc_TrEGI (Figure 4D and 4E) is > 2.5-fold better than Sc_TrEGI (Figure 4A and 4B) at hydrolyzing Avicel at $60^{\circ} \mathrm{C}$ and IL-Avicel at $65^{\circ} \mathrm{C}$. In addition, the activity of G230A/D113S/D115T Sc_TrEGI at $60^{\circ} \mathrm{C}$ against Avicel and IL-Avicel is similar to that of Sc_TrEGI at $50^{\circ} \mathrm{C}$ on these substrates. Hence, B-factor guided engineering of TrEGI provided variants with

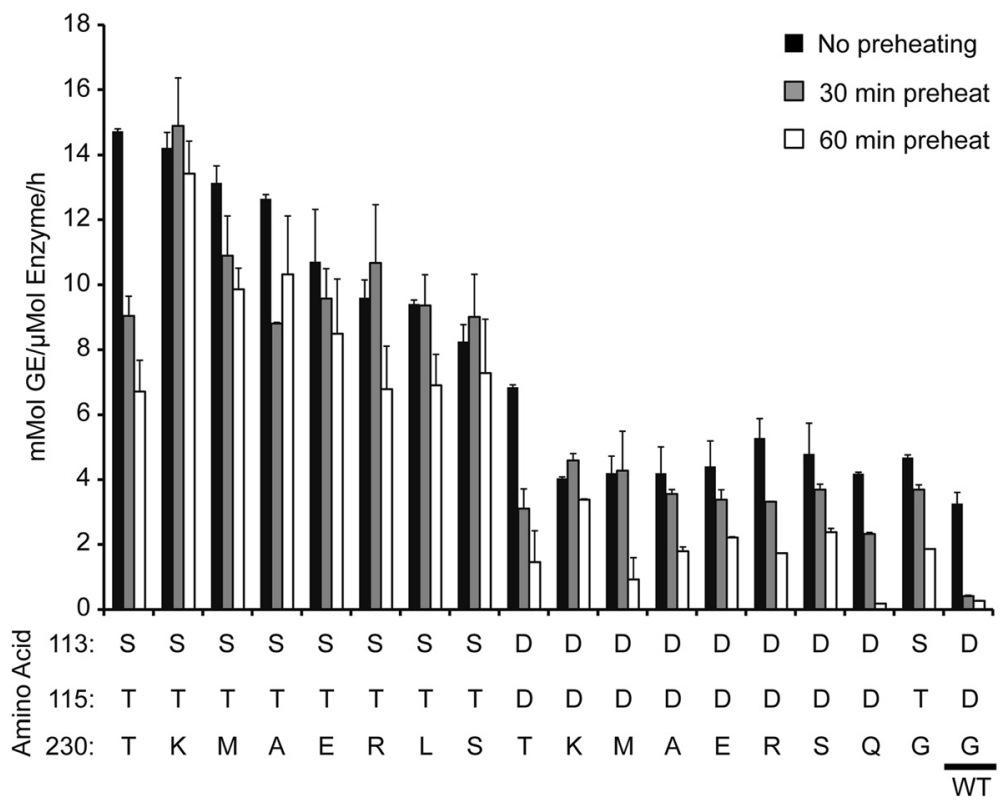

Figure 3 Activity of $\mathbf{T}$. reesei endoglucanase I mutants at $50^{\circ} \mathbf{C}$ on $\mathbf{C M C}$. Error bars represent one standard deviation. TrEGl proteins were expressed using cell-free protein synthesis and were used without any purification. 

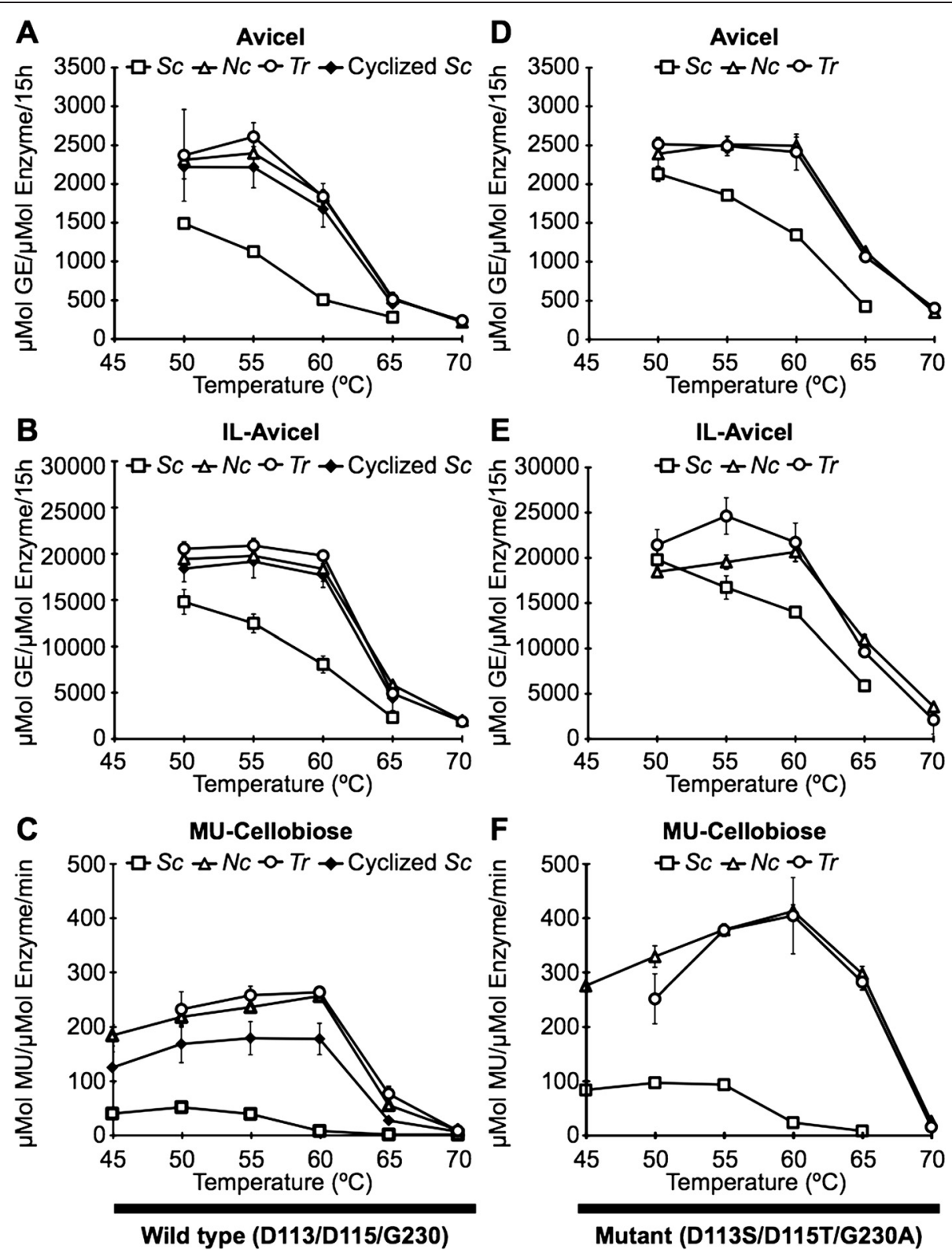

Figure 4 Temperature activity profile of wild-type T. reesei endoglucanase I (A-C) and G230A/D113S/D115T mutant (D-F) on Avicel (A,D), IL-Avicel (B,E), and MU-Cellobiose (C,F) expressed in S. cerevisiae, N. crassa, T. reesei , and S. cerevisiae followed by N-terminal cyclization of the wild-type TrEGI with gutaminyl cyclase. Error bars represent one standard deviation. Assays were carried out with purified TrEGl proteins ( $>95 \%$ pure based on SDS-PAGE analysis).

hydrolytic activities on Avicel and IL-Avicel at $60^{\circ} \mathrm{C}$ similar to the activity of Sc_TrEGI toward these same substrates at $50^{\circ} \mathrm{C}$.

All of the engineered triple mutants expressed in $S$. cerevisiae exhibited higher apparent melting temperatures $\left(\mathrm{T}_{\mathrm{m}}=58-61^{\circ} \mathrm{C}\right.$; measurements were performed as described in Methods using differential scanning calorimetry) than Sc_TrEGI $\left(\mathrm{T}_{\mathrm{m}}=57^{\circ} \mathrm{C}\right)$. Mutant G230A/ D113S/D115T Sc_TrEGI $\left(\mathrm{T}_{\mathrm{m}}=61^{\circ} \mathrm{C}\right.$, Table 1$)$ showed a $\sim 4^{\circ} \mathrm{C}$ increase in apparent melting temperature over
Sc_TrEGI. No significant difference in half-life at $70^{\circ} \mathrm{C}$ was observed between Sc_TrEGI and this mutant (Table 1). It is important to note that our initial efforts included expressing the TrEGI enzymes bearing a Cterminal his ${ }_{6}$ tag, which lowered their activity on Avicel (up to 3-fold; compare Additional file 1: Figure S4A and Figure S5), but had little effect on their activity on ILAvicel (data not shown). This result suggests abrogated binding to Avicel of TrEGI enzymes bearing a Cterminal his ${ }_{6}$ tag. 
Table 1 Biochemical characterization of TrEGI expressed in different hosts

\begin{tabular}{|c|c|c|c|c|c|c|}
\hline \multirow[t]{2}{*}{ Expression host } & \multirow[t]{2}{*}{ Enzyme } & \multirow[t]{2}{*}{$\mathrm{T}_{\mathrm{m}}\left({ }^{\circ} \mathrm{C}\right)$} & \multicolumn{4}{|l|}{$t_{1 / 2}(h r)$} \\
\hline & & & $50^{\circ} \mathrm{C}$ & $60^{\circ} \mathrm{C}$ & $65^{\circ} \mathrm{C}$ & $70^{\circ} \mathrm{C}$ \\
\hline S. cerevisiae & WT & 57 & - & - & - & $3(0.4)$ \\
\hline S. cerevisiae & G230A/D113S/D115T & 61 & - & - & - & $3.7(0.5)$ \\
\hline S. cerevisiae & WT + Glutaminyl Cyclase & 65 & - & - & - & - \\
\hline N. crassa & WT & 65 & $>5$ days & $70.6(3.5)$ & $4.0(0.2)$ & $3.3(0.1)$ \\
\hline N. crassa & G230A/D113S/D115T & 68 & $>5$ days & $176(16)$ & $3.3(0.3)$ & $3.5(0.4)$ \\
\hline T. reesei & WT & 65 & $>5$ days & $74(2.5)$ & $5.8(0.6)$ & $6.2(0.4)$ \\
\hline T. reesei & G230A/D113S/D115T & 68 & $>5$ days & $161(5)$ & $6.2(0.7)$ & $6.4(0.3)$ \\
\hline
\end{tabular}

$T_{m}$ is the apparent melting temperature for the enzyme, and $t_{1 / 2}$ is half-life in hours. - $=$ Not determined. Errors are reported in parentheses and represent one standard deviation for measurements. Apparent melting temperature data for Sc_TrEGI (with and without glutaminyl cyclase treatment) and Tr_TrEGl are shown in (Additional file 1: Figure S9). Apparent melting temperature data are not shown for other TrEGl enzymes. Half-life measurements for $T$. reesei- and N. crassa-expressed enzymes are shown in (Additional file 1: Figure S6 and Figure S7), respectively. Half-life measurements for S. cerevisiae-expressed TrEGI enzymes are not shown.

\section{Characterization of Trichoderma reesei endoglucanase I variants expressed in the filamentous fungi $N$. crass $a$ and T. reesei}

Sc_TrEGI showed a much lower apparent melting temperature $\left(\mathrm{T}_{\mathrm{m}}=57^{\circ} \mathrm{C}\right)$ and temperature optimum $\left(50^{\circ} \mathrm{C}\right)$ compared to the native TrEGI $\left(\mathrm{T}_{\mathrm{m}} \sim 65^{\circ} \mathrm{C}, \mathrm{T}_{\text {opt }} 60^{\circ} \mathrm{C}\right)$ [18], which could be due to non-optimal folding and/or aberrant glycosylation of TrEGI when expressed in S. cerevisiae. In order to investigate these possibilities, and to compare the properties (activity and stability) of the engineered TrEGI enzymes to the native TrEGI, we pursued TrEGI expression in $T$. reesei. Thus the wild-type TrEGI and the best mutant (G230A/D113S/D115T TrEGI) were expressed in $T$. reesei QM9414. In addition, our interest in evaluating alternative filamentous fungal systems for cellulase expression prompted us to express TrEGI enzymes (wildtype, G230A/D113S/D115T, and G230E/D113S/D115T) in the filamentous fungus $N$. crassa, which is closely related to T. reesei. TrEGI enzymes (wild-type or G230A/ D113S/D115T) expressed in T. reesei and N. crassa were found to have identical temperature optima on MUcellobiose (Figure 4C, 4F), and apparent melting temperatures (Table 1), which in the case of wild-type enzyme (Tr_TrEGI and Nc_TrEGI) is also identical to the values reported previously for the native TrEGI. Furthermore, little difference was observed between their activities on solid substrates Avicel (Figure 4A) and ILAvicel (Figure 4B), thus validating N. crassa as a suitable surrogate of $T$. reesei for TrEGI production.

G230A/D113S/D115T Tr_TrEGI showed similar or higher activity on solid substrates (Figure 4D and 4E) than Tr_TrEGI when assayed at $50-70^{\circ} \mathrm{C}$ (Figure $4 \mathrm{~A}$ and $4 \mathrm{~B}$ ); specifically, a $\sim 2$-fold increase in activity was observed at $65^{\circ} \mathrm{C}$. In addition, G230A/D113S/D115T Tr_TrEGI showed similar hydrolytic activity on solid substrates at $60^{\circ} \mathrm{C}$ as the Tr_TrEGI at $50^{\circ} \mathrm{C}$. As expected, similar improvements were also observed for $N$. crassa-expressed TrEGI variants.
Hence, B-factor guided engineering of TrEGI provided variants with hydrolytic activities on Avicel and IL-Avicel at $60^{\circ}$ $\mathrm{C}$ similar to the activity of $\mathrm{Tr}$ - TrEGI toward these same substrates at $50^{\circ} \mathrm{C}$.

G230A/D113S/D115T Tr_TrEGI $\left(\mathrm{T}_{\mathrm{m}}=68^{\circ} \mathrm{C}\right)$, G230A/ D113S/D115T Nc_TrEGI $\left(T_{m}=68^{\circ} \mathrm{C}\right)$, and G230E/D113S/ D115T Nc_TrEGI $\left(\mathrm{T}_{\mathrm{m}}=68^{\circ} \mathrm{C}\right)$ showed a $3^{\circ} \mathrm{C}$ increase in apparent melting temperature (Table 1 and, Additional file 1: Table S1) compared to $\operatorname{Tr} \_$TrEGI or Nc_TrEGI $\left(T_{m}=65^{\circ} \mathrm{C}\right)$. In order to assess whether the thermostable mutants also show improved half-lives over the wild-type TrEGI, half-lives of the thermostable mutant G230A/ D113S/D115T TrEGI and the wild-type TrEGI (T. reeseior $N$. crassa-expressed) were measured at $50^{\circ} \mathrm{C}, 60^{\circ} \mathrm{C}, 65^{\circ} \mathrm{C}$ and $70^{\circ} \mathrm{C}$ (Table 1 and Additional file 1: Figure S6-S7). Although the half-life for TrEGI enzymes at $50^{\circ} \mathrm{C}$ was too long ( $>5$ days) to distinguish any gains made at this temperature (data not shown), the G230A/D113S/D115T TrEGI variant showed a $>2$-fold increase in half-life at $60^{\circ} \mathrm{C}$ compared to the corresponding recombinant (T. reesei or $N$. crassa) wild-type TrEGI (Table 1 ). The improved halflife $\left(\mathrm{t}_{1 / 2}=161 \mathrm{hr}\right)$ of the G230A/D113S/D115T Tr_TrEGI variant at $60^{\circ} \mathrm{C}$ results in improved or comparable performance of this mutant in biomass saccharification carried out at $60^{\circ} \mathrm{C}$ compared to the performance of $\mathrm{Tr}$. TrEGI at $50^{\circ} \mathrm{C}$ (Figure 4A, B, D and E). We also expect that the increased stability and half-life of the G230A/D113S/ D115T Tr_TrEGI at temperatures such as $60^{\circ} \mathrm{C}$ will correlate with improved half-life at lower temperatures $\left(\leq 60^{\circ} \mathrm{C}\right)$ compared to $\operatorname{Tr}_{-} \operatorname{TrEGI}$. The half-lives of both these enzymes were significantly shorter $(\sim 3-6 \mathrm{hr})$ (Table 1) at higher temperatures $\left(65^{\circ} \mathrm{C}\right.$ and $\left.70^{\circ} \mathrm{C}\right)$. It is surprising that little or no difference was found between the half-lives of G230A/D11S/D115T TrEGI and the wild-type enzyme ( $T$. reesei- or $N$. crassa-expressed) at either $65^{\circ} \mathrm{C}$ or $70^{\circ} \mathrm{C}$ (Table 1), which may reflect a shift in the inactivation mechanism(s) with temperature 
mediated by the different enzyme structures and/or glycosylation patterns as observed previously with other $\beta$ sandwich or multi-domain proteins $[28,29]$.

\section{Impact of N-terminal pyroglutamate on activity and stability of $T$. reesei endoglucanase I}

TrEGI and G230A/D113S/D115T TrEGI expressed in both $T$. reesei and $N$. crassa were found to have much higher $\mathrm{T}_{\mathrm{m}}$ values $\left(7-8^{\circ} \mathrm{C}\right.$ difference) than their $S$. cerevisiae-expressed counterparts (Table 1 ). In addition, they were up to 3.6-fold more active on Avicel (Figure 4A and D) at $50-65^{\circ} \mathrm{C}$ and up to 2.5 -fold more active on ILAvicel (Figure $4 \mathrm{~B}$ and $\mathrm{E}$ ) at $50-65^{\circ} \mathrm{C}$ compared to their counterparts expressed in S. cerevisiae. Given the similarity of molecular weights of the TrEGI glycoforms expressed in S. cerevisiae and N. crassa (Additional file 1: Figure S8), the lower stability and activity of S. cerevisiae TrEGI could potentially be due to non-optimal folding (due to protein modifications or lack thereof) and/or incorrect disulfide formation upon expression in S. cerevisiae. In this connection, we investigated the role of $\mathrm{N}$ terminal pyroglutamate observed in the $T$. reesei EGI crystal structure.

The available crystal structure of $T$. reesei EGI (pdb code 1EGI) [7] reveals a buried $\mathrm{N}$-terminal pyroglutamate in the natively-expressed enzyme resulting from the cyclization of the $\mathrm{N}$-terminal glutamine. We hypothesized that the lack of this $\mathrm{N}$-terminal glutamine cyclization (confirmed by N-terminal sequencing of $S$. cerevisiae-expressed TrEGI enzyme) in S. cerevisiaeexpressed enzyme would most likely result in nonoptimal protein structure and contribute to the observed decreased stability and activity compared to the $T$. reesei-expressed enzyme. Glutaminyl cyclases (E.C. 2.3.2.5) are known to catalyze the irreversible lactamization of a $\mathrm{N}$-terminal glutamine to a hydrophobic pyroglutamate in many proteins and peptides [30]. Using a human glutaminyl cyclase enzyme [31] we cyclized the $\mathrm{N}$-terminal glutamine residue of Sc_TrEGI to a pyroglutamate, as evidenced by a blocked $\mathrm{N}$-terminal sequence, typical of proteins/peptides with $\mathrm{N}$-terminal pyroglutamate [32].

Treating Sc_TrEGI with the human glutaminyl cyclase substantially increased its activity on solid substrates compared to the corresponding enzyme without glutaminylcyclase treatment (Figure 4A-B), and shifted its temperature optimum from $50^{\circ} \mathrm{C}$ to $60^{\circ} \mathrm{C}$ on soluble substrates (Figure 4C). The activity of the glutaminyl-cyclase treated Sc_TrEGI on Avicel and IL-Avicel is similar if not identical to its counterpart expressed in $T$. reesei or $N$. crassa (Figure 4A-B).

The increased stability of Sc_TrEGI from N-terminal glutamine cyclization was evaluated by measurements of apparent melting temperatures (Additional file 1: Figure S9). Glutaminyl-cyclase treated Sc_TrEGI $\left(\mathrm{T}_{\mathrm{m}}=65^{\circ} \mathrm{C}\right)$ showed an $\sim 8^{\circ} \mathrm{C}$ increase in apparent melting temperature compared to the corresponding uncyclized version (Table 1). The apparent melting temperature of Sc_TrEGI upon cyclization (Table 1) was identical to that of Tr_EGI $\left(\mathrm{T}_{\mathrm{m}}=\right.$ $65^{\circ} \mathrm{C}$ ). The large increase in $\mathrm{T}_{\mathrm{m}}$ upon $\mathrm{N}$-terminal glutamine cyclization indicates that the lower stability of the S. cerevisiae enzymes is due to the uncyclized $\mathrm{N}$-terminal glutamine. In addition, it is worth noting that the differences in glycosylation between Sc_TrEGI and Nc_TrEGI (Additional file 1: Figure S8) are irrelevant to the activity and stability differences between these enzymes in comparison to the cyclization of the N-terminal glutamine. Recently our group also demonstrated a similar increase in stability and activity upon cyclization of $\mathrm{N}$-terminal glutamine to pyroglutamate in S. cerevisiae-expressed Talaromyces emersonii Cel7A [33]. The ubiquitous presence of the $\mathrm{N}$-terminal pyroglutamate in GH7 enzymes (Cel7A and Cel7B), along with its role in imparting high stability/activity for these enzymes, highlights the importance of N-terminal glutamine cyclization for achieving high-efficiency cellulases.

\section{Impact of mutagenesis and expression host on activity and stability of $T$. reesei endoglucanase I}

Combinations of TrEGI mutations at amino acids G230, and D113/D115 identified using the B-factor method resulted in improved TrEGI enzymes irrespective of the expression host for the enzyme. In particular, TrEGI mutant G230A/D113S/D115T showed improved activity on solid substrates as well as improved thermostability for each expression host when compared to wild-type TrEGI enzyme expressed in the same host. These mutations may rigidify the mobile portions of the TrEGI enzyme, and thus enhance its stability. In particular, it is likely that the mutation at G230, which is located on a solvent exposed loop, imparts improved stability by reducing the entropy (rigidifying) of the (partially) unfolded TrEGI, a well-known mechanism for improving protein stability by replacing conformationally flexible residues such as glycine (located in loops or secondary structural elements) with more rigid residues such as alanine [34,35]. Removal of unfavorable electrostatic interactions involving negative charges on D113/D115 in the wild-type enzyme could also lead to increased stability [36]. A small difference in mass was observed between Nc_TrEGI and G230A/D113S/D115T Nc_TrEGI (mass difference $=0-2 \mathrm{Da}$, Additional file 1 : Figure S8 C/D) and between Sc_TrEGI and G230A/D113S/ D115T Sc_TrEGI (mass difference $=2-59 \mathrm{Da}$, Additional file 1: Figure $S 8 \mathrm{~A} / \mathrm{B}$ ), after accounting for the mass difference resulting from the G230A/D113S/D115T mutation. This shows that there is little or no difference in the extent of glycosylation (total glycan content $=8-10 \mathrm{kDa}$ ) between the wild-type TrEGI and the mutant G230A/D113S/D115T TrEGI when they are expressed in the same fungal host. Thus, the improved stability of G230A/D113S/D115T 
TrEGI compared to wild-type TrEGI when expressed in either $N$. crassa or $S$. cerevisiae is due to the G230A/ D113S/D115T mutation and not due to changes in glycosylation.

The specific activity of TrEGI enzymes (wild-type and G230A/D113S/D115T) on solid substrates was dramatically altered upon expression in different hosts (cell-free, $S$. cerevisiae, $N$. crassa, and T. reesei) with $T$. reesei or $N$. crassa producing the most active enzymes on Avicel and IL-Avicel (Figure 4). Glycosylation of TrEGI enzymes renders them more thermostable compared to their cell-free expressed counterparts, which is consistent with previous reports showing the importance of glycosylation in protein thermostability [20-22,24]. The cyclization of N-terminal glutamine to a pyroglutamate in S. cerevisiae expressed TrEGI resulted in a TrEGI enzyme with near identical properties to the natively expressed enzyme.

\section{Conclusions}

Using B-factor guided mutagenesis, T.reesei endoglucanase I variants were developed that were up to 2 -fold more active on solid cellulosic substrates at $65^{\circ} \mathrm{C}$ than the recombinant wild-type enzyme expressed in the same hosts, and exhibited the same activity at $60^{\circ} \mathrm{C}$ as the recombinant wild-type enzyme at $50^{\circ} \mathrm{C}$. The most stable TrEGI mutant G230A/D113S/D115T showed a $\sim 3^{\circ} \mathrm{C}$ increase in $\mathrm{T}_{\mathrm{m}}$, as well as more than 2-fold improved half-life at $60^{\circ} \mathrm{C}$ over the native TrEGI. Amino acid changes at G230 coupled with the D113S/D115T double mutation in TrEGI gave rise to variants with improved thermostability and activity at $50-70^{\circ} \mathrm{C}$, irrespective of their expression host. However, the stability and activity of the TrEGI enzymes varied significantly when expressed using $E$. coli cell extract, $S$. cerevisiae, $N$. crassa, or T. reesei. TrEGI variants expressed in $N$. crassa or $T$. reesei yielded the most active and stable TrEGI enzymes and S. cerevisiae yielded inferior TrEGI enzymes. Cyclization of $\mathrm{N}$-terminal glutamine to a pyroglutamate in S. cerevisiae-expressed TrEGI improved its properties to closely match those of the native enzyme, highlighting the importance of this ubiquitous modification in Cel7B enzymes. In this study we show that a nonglycosylating host can be used to screen and discover thermostability imparting mutations in fungal enzymes that result in improved enzymes irrespective of the protein production host. The choice of host for protein engineering of cellulases may not be as critical as the protein production host, which plays a major role in determining the properties of the expressed enzymes.

\section{Methods}

All experiments were carried out using either purified TrEGI enzymes (when expressed in S. cerevisiae, $N$. crassa, or T. reesei) or TrEGI enzymes expressed via cellfree protein synthesis without any purification. Purity of purified enzymes (>95\%) was determined using SDSPAGE analysis with Coomassie blue dye staining.

Construction of plasmid bearing $T$. reesei endoglucanase I Gene for the T. reesei endoglucanse I (cel7b, UniProt No. P07981) synthesized with E. coli codon bias was purchased from GenScript (Genscript Corporation, Piscatway, NJ, USA). The structural gene of cel7b was PCR-amplified from plasmid pUC57-P07981 by using the forward primer (5'AAAAAACATATG CAACAACCGGGCACCTCC-3') and reverse primer $\left(5{ }^{\prime}\right.$-AAAAAAGTCGACTTACAGACATTG CGAGTAGTA-3'). PCR product was then cloned into pIVEX2.4d vector (Roche Applied Science) after a double digestion with NdeI and SalI to generate plasmid, pIVEX2.4d-TrEG1.

\section{Preparation of S30 cell-extract}

The cell-extracts were prepared as reported previously [16]. To exhaust the reducing activity of cell-extract, the S30 extract was incubated with $10 \mathrm{mM}$ oxidized glutathione for $2 \mathrm{hrs}$ at $30^{\circ} \mathrm{C}$. The residual glutathione molecules were removed by dialyzing the treated extract against 200 volumes of buffer C (buffer A without DTT and 2-ME) for $3 \mathrm{hrs}$ at $4^{\circ} \mathrm{C}$. The resulting extract was divided into small aliquots and stored at $-80^{\circ} \mathrm{C}$ before using it for cell-free protein synthesis.

\section{Site directed mutagenesis of $T$. reesei endoglucanase I}

Site directed mutagenesis at amino acids 238, 291, and 323 of T. reesei EGI (pIVEX2.4d-TrEG1 as template plasmid) was performed using the site directed mutagenesis kit (Stratagene) by following the manufacturers protocol with primers shown in Additional file 1: Table S2. Mutagenesis at sites with amino acids 230, 113 and 115, 284287, and 301-302 of T. reesei EGI (pIVEX2.4d-TrEG1 as template plasmid) was performed using Overlap Extension PCR. All PCR reactions were carried out using Pfu DNA polymerase (Stratagene, La Jolla, CA). The plasmids were transformed into electrocompetent XL1 Blue cells and plated. Colonies were picked and transferred into 96-well plates using a colony picker (Qpix) and grown overnight at $37^{\circ} \mathrm{C}$ in $10 \%$ glycerol containing LB medium. For site A, $\sim 3000$ colonies were picked, corresponding to $\sim 2 \%$ coverage; for all other sites, colonies corresponding to $>95 \%$ coverage of sequence space were picked and grown overnight in 96-well plates ( 3000 colonies for sites B and C, and $\sim 500$ colonies for sites D-G).

\section{Cell-free protein synthesis}

Overnight culture bearing the mutant $T$. reesei EGI gene was used as a template for the PCR reaction. TrEGI DNA amplified by PCR using T7 fwd and T7 rev primers served as template for protein synthesis. The standard reaction mixture for cell-free protein synthesis consisted of the 
following components in a total volume of $15 \mu \mathrm{L}: 57 \mathrm{mM}$ of Hepes-KOH (pH 7.5); $1.2 \mathrm{mM}$ of ATP; $0.85 \mathrm{mM}$ each of CTP, GTP, and UTP; $0.17 \mathrm{mg} / \mathrm{mL}$ of E.coli total tRNA mixture (from stain MRE600); $90 \mathrm{mM}$ of potassium glutamate; $80 \mathrm{mM}$ of ammonium acetate; $12 \mathrm{mM}$ of magnesium acetate; $34 \mu \mathrm{g} / \mathrm{mL}$ of L-5-formyl-5, 6, 7, 8-tetrahydrofolic acid (folinic acid); $2.0 \mathrm{mM}$ each of all 20 amino acids; 2\% PEG (8000); $67 \mathrm{mM}$ of creatine phosphate $(\mathrm{CP}) ; 3.2 \mu \mathrm{g} / \mathrm{mL}$ of creatine kinase (CK); $2.5 \mathrm{mM}$ oxidized glutathione; $2.5 \mathrm{mM}$ reduced glutathione; $16.7 \mu \mathrm{g} / \mathrm{mL}$ of PCR product; $27 \%(\mathrm{v} / \mathrm{v})$ of S30-GroEL/ES cell-extract. The cell-free reaction was conducted at $30^{\circ} \mathrm{C}$ for 2 hours. For determining the amount of the protein synthesized using the cell-free synthesis, $10 \mu \mathrm{M}$ of L- $\left[\mathrm{U}_{-}{ }^{14} \mathrm{C}\right]$ Leucine $(11.3 \mathrm{GBq} / \mathrm{mmol}$, Amersham Biosciences) was also added to the cell-free reaction. To analyze the solubility of cell-free expressed protein, the cellfree mixture was centrifuged at 15,000 rpm for $10 \mathrm{~min}$ at $4^{\circ} \mathrm{C}$. The soluble amount of synthesized protein was determined by analyzing the supernatant of the centrifugation. The amount of each cell-free synthesized cellulase was estimated from the TCA-insoluble radioactivity using a liquid scintillation counter (Tri-Carb 2810TR Liquid Scintillation Analyzer, Perkin-Elmer Inc.).

\section{Screening $T$. reesei endoglucanase I mutants for improved thermostability/activity}

Two $\mu \mathrm{L}$ of $1 \mathrm{M}$ sodium acetate buffer $\mathrm{pH} 4.85$ was added to $15 \mu \mathrm{L}$ of cell-free expressed TrEGI mutant to lower the $\mathrm{pH}$ to 5 . TrEGI mutant was then heated to $50^{\circ} \mathrm{C}$ for 30 mins after which $1 \mu \mathrm{L}$ was spotted on CMC-agar plate $(1 \% \mathrm{CMC}$, $1.5 \%$ agar, $50 \mathrm{mM} \mathrm{pH} 4.85$ Acetate buffer) and incubated overnight $(12-16 \mathrm{hr})$ at $50^{\circ} \mathrm{C}$. The $\mathrm{CMC}$-agar plates were stained with $15 \mathrm{~mL}$ of $1 \%$ congo red for 5 mins. The plates were then analyzed for presence of clearing zones, which represented active enzymes (hits). All experiments were carried out using TrEGI enzymes expressed using cell-free protein synthesis without any purification.

\section{Measuring the thermostability of Trichoderma reesei endoglucanase I}

To measure the thermostability of TrEG1, $10 \mu \mathrm{L}$ of the cell-free synthesized TrEG1 (20 pmol) was mixed with $10 \mu \mathrm{L}$ of $200 \mathrm{mM}$ of sodium acetate buffer ( $\mathrm{pH} 4.85$ ). After incubating the enzyme mixture at $50^{\circ} \mathrm{C}$ with different incubation time points $(0,15,30,45,60 \mathrm{~min}), 80 \mu \mathrm{L}$ of $1.25 \%(\mathrm{w} / \mathrm{v}) \mathrm{CMC}$ containing $100 \mathrm{mM}$ sodium acetate buffer ( $\mathrm{pH} 4.85$ ) was added into the heat-pretreated enzyme mixture to start hydrolysis reaction for $1 \mathrm{hr}$ at $50^{\circ}$ C. The reducing sugar concentration was measured by the DNS assay as described previously [16]. All experiments were carried out in triplicate using TrEGI enzymes expressed via cell-free protein synthesis without any purification.

\section{Endoglucanase activity measurement on solid cellulosic substrates}

All cellulolytic assays for solid substrates were carried out in quadruplicate in 96-well plates in a final volume of $70 \mu \mathrm{L}$ containing $1 \%(\mathrm{w} / \mathrm{v})$ substrate, $100 \mathrm{mM}$ sodium acetate buffer $\mathrm{pH} 4.85,0.2 \mu \mathrm{M}$ of the cellulase at $50-70^{\circ} \mathrm{C}$. The 96-well plates were sealed with aluminum foil and incubated without shaking in a thermocycler with a heated top to minimize evaporation. Cellulase activities were measured for Avicel, and ionic-liquid pretreated Avicel (IL-Avicel). The mixtures were incubated at $50-70^{\circ} \mathrm{C}$ for $15 \mathrm{~h}$ after which they were cooled to $4^{\circ} \mathrm{C}$ prior to measuring the amount of soluble reducing sugar released using the glucose oxidase-peroxidase assay as described previously [16]. IL-avicel was prepared as described previously [16]. All experiments were carried out using either purified TrEGI enzymes (when expressed in S. cerevisiae, $N$. crassa, or $T$. reesei) or TrEGI enzymes expressed via cellfree protein synthesis without any purification. Enzyme purity (>95\%) was determined using SDS-PAGE analysis with Coomassie blue dye staining.

\section{Expression of $T$. reesei endoglucanase I in S. cerevisiae}

For production of $T$. reesei EGI and engineered mutants in $S$. cerevisiae, the corresponding genes $(E$. coli codon optimized as described above) were amplified from pIVEX $2.4 \mathrm{~d}$ vector and were cloned with and without a his6 tag on the C-terminus in $\mathrm{pCu} 424$ vector [37]. An engineered $\alpha$-factor AppS4 [38] prepro leader sequence was appended onto the N-terminus of the genes to enable secretion of the enzyme. pCu424 containing T. reesei EG1 gene was transformed into S. cerevisiae strain YVH10 [39] with additional PMR1 knockout using the LiAc method [40]. For expression, a saturated YPD medium preculture was used to inoculate $1 \mathrm{~L}$ selective medium (SC-Trp) and grown for three days at $30^{\circ} \mathrm{C}$. The culture was spun down at $4000 \mathrm{~g}$ for $5 \mathrm{~min}$ and resuspended in YPD medium supplemented with $500 \mu \mathrm{M} \mathrm{CuSO}_{4}$ for a three-day induction at $25^{\circ} \mathrm{C}$. Culture supernatant was concentrated to $\sim 100 \mathrm{~mL}$ (10 kDa cut-off) prior to purification. TrEGI bearing the his6 tag was purified from culture supernatant using Niaffinity chromatography. TrEGI without the his6 tag was purified from culture supernatant as described below for N. crassa TrEGI.

\section{Deglycosylation of $T$. reesei endoglucanase I expressed in S. cerevisiae}

Three to five mg of purified T. reesei EG1 expressed in S. cerevisiae was incubated in $\mathrm{pH}$ 7.0, $25 \mathrm{mM}$ phosphate buffer along with 200 units of PNGase F (NEB) at $30^{\circ} \mathrm{C}$ for $18 \mathrm{~h}$ following which an additional 100 units of PNGase F were added and incubated for another $24 \mathrm{~h}$. PNGase $\mathrm{F}$ treated $T$. reesei EG1 was purified using gel filtration chromatography. 
Temperature optima of $T$. reesei endoglucanase I expressed in S. cerevisiae, N. crassa, and T. reesei

To measure the temperature optima, TrEG1 and the mutants expressed in $S$. cerevisiae (glycosylated versions) and $T$. reesei were assayed for $10 \mathrm{~min}$ at different temperatures $\left(40^{\circ} \mathrm{C}-65^{\circ} \mathrm{C}\right)$ using $1 \mathrm{mM}$ MU-cellobiose in $100 \mathrm{mM}$ sodium acetate buffer $(\mathrm{pH} 4.85)$ as the substrate in a $100 \mu \mathrm{L}$ reaction volume in a PCR thermocycler. The reaction was quenched by adding $5 \mu \mathrm{L}$ of the reaction mixture to $145 \mu \mathrm{L} 110 \mathrm{mM}$ CAPS buffer, $\mathrm{pH}$ 10.8. Activity was determined by measuring the fluorescence of methyl umbelliferone released. The TrEGI enzyme concentration ranged from $0.1-0.5 \mu \mathrm{M}$ for initial-rate measurements. All experiments were carried out in quadruplicate. All experiments were carried out using purified enzymes.

\section{Half-life measurements of $T$. reesei endoglucanase I expressed in S. cerevisiae, N.crassa, and T. reesei} TrEGI enzymes $(1 \mu \mathrm{M})$ were incubated in $100 \mathrm{mM}$ sodium acetate buffer $\mathrm{pH} 4.85$ at $50^{\circ} \mathrm{C}, 60^{\circ} \mathrm{C}, 65^{\circ} \mathrm{C}$ and $70^{\circ} \mathrm{C}$ in a PCR thermocycler. Aliquots were withdrawn at different times and incubated at $4^{\circ} \mathrm{C}$ for $20 \mathrm{~min}$. Endoglucanase activity was measured at $50^{\circ} \mathrm{C}$ using MU-cellobiose as described above. The enzyme half-life was calculated by fitting the activity data to exponential or linear functions. All experiments were carried out in duplicate. All experiments were carried out using purified enzymes.

\section{Cloning, expression and purification of $T$. reesei endoglucanase I in $\mathbf{N}$. crassa}

T. reesei EGI and engineered mutants were expressed in $N$. crassa as described previously [33]. The wild-type TrEGI gene was amplified from $T$. reesei gDNA. The engineered TrEGI mutants were constructed using sitedirected mutagenesis kit from Stratagene as described above. TrEGI was purified from culture supernatant in a series of steps. TrEGI was precipitated from the culture supernatant with $65 \%$ ammonium sulfate. The supernatant was spun down and the precipitated proteins were resuspended $20 \mathrm{mM}$ Tris- $\mathrm{HCl} \mathrm{pH} 7$ buffer and desalted using HiPrep 26/10 desalting column with $20 \mathrm{mM}$ Tris- $\mathrm{HCl} \mathrm{pH} 7$ as the running buffer. The protein was then concentrated and loaded on Mono Q column and TrEGI was eluted using $20 \mathrm{mM}$ Tris- $\mathrm{HCl}$ pH 7 buffer between 25-75 mM NaCl. TrEGI containing fractions were pooled and further polished using size exclusion chromatography to give pure protein.

\section{Cloning, expression and purification of Trichoderma reesei endoglucanase I in $T$. reesei}

For production of $T$. reesei EGI and engineered mutants a EGI expression vector was constructed by introducing the EGI gene followed by the $N$. crassa cbhI terminator behind the cdna1 promoter in pPcdnal expression plasmid (generous gift from Bernhard Seiboth) [41]. Transformation of $T$. reesei by electroporation was adapted as described previously [42]. Spores of T. reesei QM9414 were harvested from a $90 \mathrm{~mm}$ potato dextrose agar (PDA) plate and suspended in 1.1 M ice cold sorbitol. Spores were washed twice with $1.1 \mathrm{M}$ ice cold sorbitol, pelleted at 800xg for $4 \mathrm{~min}$, and then re-suspended in $100 \mathrm{uL}$ of $1.1 \mathrm{M}$ ice cold sorbitol. Two micrograms of purified PCR product of the expression cassette using the primers 5'- GGATCCGA GAGCTACCTTACATC -3' and 5'- CGAACTACCTCG CGAAACTCG -3' was added to the spore suspension and incubated on ice for $30 \mathrm{~min}$. Electroporation was conducted using a Gene Pulser Xcell (Bio-Rad Laboratories, Inc., Hercules, CA) in $1 \mathrm{~mm}$ gap cuvette at $1.6 \mathrm{kV}, 600 \Omega$ and $25 \mu \mathrm{F}$. Immediately following electroporation, $900 \mu \mathrm{L}$ of $1.1 \mathrm{M}$ ice cold sorbitol was added and gently mixed. The spore suspension was then added to $9 \mathrm{~mL}$ of YPD (1\% $(\mathrm{w} / \mathrm{v})$ yeast extract, $2 \%(\mathrm{w} / \mathrm{v})$ peptone, $2 \%(\mathrm{w} / \mathrm{v})$ dextrose) and incubated for $12 \mathrm{hr}$ at room temperature. Spores were pelleted at $800 \mathrm{xg}$ for $4 \mathrm{~min}$, re-suspended in $1 \mathrm{~mL}$ of $1.1 \mathrm{M}$ sorbitol, and plated using the overlay method onto Mandels-Andreotti medium containing $200 \mu \mathrm{g} / \mathrm{mL}$ hygromycin B. Both top and bottom agars contained hygromycin B. Germinated spores were picked onto PDA slants containing hygromycin B. Positive transformants were selected by presence of EGI activity (AZO-CM-Cellulose Assay, Megazyme, Ireland) in the supernatant after growth in Mandels-Andreotti medium supplemented with 3\% glucose, in which QM9414 does not secrete native cellulases $[41,43]$ for 3-4 days. Culture broths were filtered through glass microfiber filters (934-AH, Whatman) followed by $0.22 \mu \mathrm{m}$ PES filters (Corning). TrEGI was purified from culture supernatant as described above for $N$. crassa TrEGI.

\section{Mass spectrometry of intact TrEGI protein}

Mass Spectra were obtained via an Agilent 6510 Quadrupole Time-of-Flight (Q-TOF) mass spectrometer immediately following external mass calibration. TrEG1 protein samples were diluted in water to a final concentration of $0.75 \mu \mathrm{M}$ and $1 \mu \mathrm{L}$ was injected using an autosampler. Samples were analyzed with an Agilent HPLC-chip cube using a custom HPLC-chip (SPQ381) containing Zorbax 300A SBC3 $(5 \mu \mathrm{m})$ separation $(43 \mathrm{~mm} \times 75 \mu \mathrm{m})$ and enrichment $(4 \mathrm{~mm}, 40 \mathrm{~nL})$ columns. Proteins were eluted under a gradient of $3 \%$ to $95 \%$ Solvent B over 9 min. Solvent A was water with $0.1 \%$ formic acid; Solvent B was acetonitrile with $0.1 \%$ formic acid. Solvent reagents were of LC/MS grade. The QTOF mass spectrometer was run under Extended Dynamic Range (2GHz). The HPLC- Chip voltage was $1.85 \mathrm{kV}$, gas temperature was $300^{\circ} \mathrm{C}$, and drying gas flow was $4 \mathrm{~L} / \mathrm{min}$. One spectra was acquired per second with $1000 \mathrm{~ms} /$ spectrum using a mass range of 300-3,000 m/z. Data analysis was performed using Agilent Mass Hunter Qualitative 
Analysis software. Mass Spectra extracted from chromatogram peaks were deconvoluted using the maximum entropy setting with a mass range of $20-80 \mathrm{kDa}$, mass step of $1 \mathrm{Da}$, $\mathrm{S} / \mathrm{N}$ threshold of 30 , minimum consecutive charge states of 5 , minimum protein fit score of 8 , and an average mass of $90 \%$ peak height.

\section{Glutaminyl Cyclase Treatment of S. cerevisiae Expressed TrEGI}

Lyophilized human glutaminyl cyclase was purchased from Sino Biological (Daxing, China; 13752-H07B) and reconstituted to $0.2 \mathrm{mg} / \mathrm{mL}$. Cyclization was carried out using $0.02 \mathrm{mg} / \mathrm{mL}$ cyclase and $50-100 \mu \mathrm{M}$ TrEGI in $50 \mathrm{mM}$ sodium phosphate $\mathrm{pH} 7.4$ for $18-48 \mathrm{~h}$ at $30^{\circ} \mathrm{C}$. Nterminal edman sequencing was performed at University of Califonia-Davis, proteomics core facility. All experiments were carried out using purified TrEGI.

\section{Differential scanning calorimetry}

The apparent melting temperature of TrEGI (0.5$1.0 \mathrm{mg} / \mathrm{mL}$ ) in $50 \mathrm{mM}$ sodium acetate, $\mathrm{pH} 4.85$, was measured using a TA Instruments NanoDSC. After equilibration, a temperature schedule from $25^{\circ} \mathrm{C}$ to $80^{\circ} \mathrm{C}$ was employed using a ramp rate of $1^{\circ} \mathrm{C} / \mathrm{min}$. Raw data are presented for some TrEGI variants (Additional file 1: Figure S9) and the apparent melting temperature corresponds to the apex of each peak. For all TrEGI enzymes mentioned herein, melting was irreversible. All experiments were carried out using purified enzymes.

\section{Additional file}

Additional file 1: Includes Figures S1-S9 and Tables S1-S2.

\begin{abstract}
Abbreviations
TrEGI: Trichoderma reesei endoglucanase I; EGl: Endoglucanase I: Sc_TrEGl: Wild-type Trichoderma reesei endoglucanase I expressed recombinantly in Saccharomyces cerevisiae; Nc_TrEGl: Wild-type Trichoderma reesei endoglucanase I expressed recombinantly in Neurospora crassa; Tr_TrEGl: Wild-type Trichoderma reesei endoglucanase I expressed recombinantly in Trichoderma reesei QM9414; CD: Catalytic Domain; CBM: Carbohydrate Binding Module; CMC: Carboxy Methyl Cellulose; DSC: Differential Scanning Calorimetry; MU-cellobiose: 4-Methyl Umbelliferone- $\beta$-D-Cellobioside; PASC: Phosphoric Acid Swollen Celulose; pNPC: $p$-Nitrophenyl- $\beta$-D-cellobioside; IL-Avicel: Ionic-liquid pretreated Avicel; $\Delta T_{50}^{60}$ : Change in temperature at which the enzyme loses half its activity after an hour of incubation.

\section{Competing interests}

A patent has been filed for the engineered Trichoderma reesei endoglucanase I variants reported herein.
\end{abstract}

\section{Authors' contributions}

HAC designed and executed the experiments and analyzed the data. CMR transformed N. crassa and T. reesei with TrEGl genes and expressed the TrEGl proteins. TWK developed the cell-free expression platform used for expressing the TrEGl and performed all TCA-insoluble radioactivity experiments. NV performed cloning of the TrEGl genes in PCSR1:GPD plasmid. MEA performed the mass spectrometry experiments. CMD developed the yeast strain and vector used for expressing the TrEGI. DSC, HWB, CMR, and HAC wrote the manuscript. All authors read and approved the manuscript.

\section{Acknowledgements}

This work was supported by the Energy Biosciences Institute. We would like to thank Dr. Trevor Starr and Prof. N. Louise Glass for providing the pCSR1: GPD plasmid for recombinant TrEGl expression in N. crassa, Dr. Bernhard Seiboth for supplying us with the pPcdna1 vector, and Dr. Jerome Fox for providing the gDNA of $T$. reesei.

\section{Author details}

${ }^{1}$ Energy Biosciences Institute, University of California, Berkeley, CA 94720, USA. ${ }^{2}$ Department of Chemical and Biomolecular Engineering, University of California, Berkeley, CA 94720, USA. ${ }^{3}$ Department of Biotechnology, Indian Institute of Technology, Kharagpur, West Bengal 721301, India. ${ }^{4}$ Department of Chemistry, University of California, Berkeley, CA 94720, USA.

Received: 3 December 2014 Accepted: 28 January 2015

Published online: 21 February 2015

\section{References}

1. Klein-Marcuschamer D, Oleskowicz-Popiel P, Simmons BA, Blanch HW. The challenge of enzyme cost in the production of lignocellulosic biofuels. Biotechnol Bioeng. 2012;109:1083-7.

2. Cherry JR, Fidantsef AL. Directed evolution of industrial enzymes: an update. Curr Opin Biotechnol. 2003;14(4):438-43.

3. Horn SJ, Vaaje-Kolstad G, Westereng B, Eijsink VG. Novel enzymes for the degradation of cellulose. Biotechnol Biofuels. 2012;5(1):45.

4. Karkehabadi S, Hansson H, Kim S, Piens K, Mitchinson C, Sandgren M. The first structure of a glycoside hydrolase family 61 member, Cel61B from Hypocrea jecorina, at 1.6 A resolution. J Mol Biol. 2008;383(1):144-54

5. Viikari L, Alapuranen M, Puranen T, Vehmaanpera J, Siika-Aho M. Thermostable enzymes in lignocellulose hydrolysis. In: Olsson L, editor. Biofuels.vol. 108. Berlin: Springer-Verlag Berlin; 2007. p. 121-45.

6. Dashtban M, Schraft H, Qin WS. Fungal Bioconversion of Lignocellulosic Residues; Opportunities \& Perspectives. Int J Biol Sci. 2009;5(6):578-95.

7. Banerjee G, Car S, Scott-Craig JS, Borrusch MS, Aslam N, Walton JD. Synthetic Enzyme Mixtures for Biomass Deconstruction: Production and Optimization of a Core Set. Biotechnol Bioeng. 2010;106(5):707-20.

8. Gao DH, Chundawat SPS, Krishnan C, Balan V, Dale BE. Mixture optimization of six core glycosyl hydrolases for maximizing saccharification of ammonia fiber expansion (AFEX) pretreated corn stover. Bioresour Technol. 2010;101(8):2770-81.

9. Kleywegt GJ, Zou JY, Divne C, Davies GJ, Sinning I, Stahlberg J, et al. The crystal structure of the catalytic core domain of endoglucanase I from Trichoderma reesei at 3.6 angstrom resolution, and a comparison with related enzymes. J Mol Biol. 1997;272(3):383-97.

10. Heinzelman P, Snow CD, Wu I, Nguyen C, Villalobos A, Govindarajan S, et al. A family of thermostable fungal cellulases created by structure-guided recombination. Proc Natl Acad Sci U S A. 2009;106(14):5610-5.

11. Liang CN, Fioroni M, Rodriguez-Ropero F, Xue YF, Schwaneberg U, Ma YH. Directed evolution of a thermophilic endoglucanase (Cel5A) into highly active Cel5A variants with an expanded temperature profile. J Biotechnol. 2011;154(1):46-53.

12. Liu WJ, Zhang XZ, Zhang ZM, Zhang YHP. Engineering of Clostridium phytofermentans Endoglucanase Cel5A for Improved Thermostability. Appl Environ Microbiol. 2010;76(14):4914-7.

13. Voutilainen SP, Boer H, Alapuranen M, Janis J, Vehmaanpera J, Koivula A. Improving the thermostability and activity of Melanocarpus albomyces cellobiohydrolase Cel7B. Appl Microbiol Biotechnol. 2009;83(2):261-72.

14. Reetz MT, Carballeira JD, Vogel A. Iterative saturation mutagenesis on the basis of $B$ factors as a strategy for increasing protein thermostability. Angew Chem Int Ed. 2006;45(46):7745-51.

15. Jochens H, Aerts D, Bornscheuer UT. Thermostabilization of an esterase by alignment-guided focussed directed evolution. Protein Engineering Design Select. 2010;23(12):903-9.

16. Kim TW, Chokhawala HA, Nadler D, Blanch HW, Clark DS. Binding Modules Alter the Activity of Chimeric Cellulases: Effects of Biomass Pretreatment and Enzyme Source. Biotechnol Bioeng. 2010;107(4):601-11.

17. Nakazawa H, Okada K, Kobayashi R, Kubota T, Onodera T, Ochiai N, et al. Characterization of the catalytic domains of Trichoderma reesei 
endoglucanase I, II, and III, expressed in Escherichia coli. Appl Microbiol Biotechnol. 2008:81(4):681-9.

18. Baker JO, Tatsumoto K, Grohmann K, Woodward J, Wichert JM, Shoemaker $\mathrm{SP}$, et al. Thermal-denaturation of trichoderma-reesei cellulases studied by differential scanning calorimetry and tryptophan fluorescence. Appl Biochem Biotechnol. 1992;34-5:217-31.

19. Firth $A E$, Patrick WM. Statistics of protein library construction. Bioinformatics. 2005;21(15):3314-5.

20. Imperiali B, O'Connor SE. Effect of N-linked glycosylation on glycopeptide and glycoprotein structure. Curr Opin Chem Biol. 1999:3(6):643-9.

21. Beckham GT, Dai Z, Matthews JF, Momany M, Payne CM, Adney WS, et al. Harnessing glycosylation to improve cellulase activity. Curr Opin Chem Biotechnol. 2012;23(3):338-45.

22. Kayser V, Chennamsetty N, Voynov V, Forrer K, Helk B, Trout BL. Glycosylation influences on the aggregation propensity of therapeutic monoclonal antibodies. Biotechnol J. 2011;6(1):38-44.

23. Jeoh T, Michener W, Himmel ME, Decker SR, Adney WS. Implications of cellobiohydrolase glycosylation for use in biomass conversion. Biotechnol Biofuels. 2008;1(1):10.

24. Adney WS, Jeoh T, Beckham GT, Chou YC, Baker JO, Michener W, et al. Probing the role of $\mathrm{N}$-linked glycans in the stability and activity of fungal cellobiohydrolases by mutational analysis. Cellulose. 2009;16(4):699-709.

25. Dana CM, Saija P, Kal SM, Bryan MB, Blanch HW, Clark DS. Biased clique shuffling reveals stabilizing mutations in cellulase Cel7A. Biotechnol Bioeng. 2012;109(11):2710-9.

26. Penttila ME, Andre L, Saloheimo M, Lehtovaara P, Knowles JKC. Expression of 2 trichoderma-reesei endoglucanases in the yeast saccharomycescerevisiae. Yeast. 1987;3(3):175-85.

27. Vanarsdell JN, Kwok S, Schweickart VL, Ladner MB, Gelfand DH, Innis MA Cloning, characterization, and expression in saccharomyces-cerevisiae of endoglucanase-i from trichoderma-reesei. Bio/Technology. 1987;5(1):60-4.

28. Werbeck ND, Rowling PJ, Chellamuthu VR, Itzhaki LS. Shifting transition states in the unfolding of a large ankyrin repeat protein. Proc Natl Acad Sci U S A. 2008;105(29):9982-7.

29. Wright CF, Lindorff-Larsen K, Randles LG, Clarke J. Parallel protein-unfolding pathways revealed and mapped. Nat Struct Biol. 2003;10(8):658-62.

30. Fischer WH, Spiess J. Identification of a mammalian glutaminyl cyclase converting glutaminyl into pyroglutamyl peptides. Proc Natl Acad Sci U S A. 1987;84(11):3628-32.

31. Huang KF, Liu YL, Wang AHJ. Cloning, expression, characterization, and crystallization of a glutaminyl cyclase from human bone marrow: A single zinc metalloenzyme. Protein Expr Purif. 2005;43(1):65-72.

32. Mozdzanowski J. Deblocking of proteins containing N-Terminal PyroglutamicAcid. In: Smith B, editor. Protein sequencing protocols. vol. 211. Totowa, NJ: Humana Press; 2003. p. 365-9.

33. Dana CM, Dotson-Fagerstrom A, Roche CM, Kal SM, Chokhawala HA, Blanch HW, et al. The importance of pyroglutamate in cellulase Cel7A. Biotechnol Bioeng. 2014;111(4):842-7.

34. Matthews BW, Nicholson H, Becktel WJ. Enhanced protein thermostability from site-directed mutations that decrease the entropy of unfolding. Proc Natl Acad Sci U S A. 1987:84(19):6663-7.

35. van den Burg B, Eijsink VG. Selection of mutations for increased protein stability. Curr Opin Biotechnol. 2002;13(4):333-7.

36. Perl D, Schmid FX. Electrostatic stabilization of a thermophilic cold shock protein. J Mol Biol. 2001;313(2):343-57.

37. Labbe S, Thiele DJ. Copper ion inducible and repressible promoter systems in yeast. In: Methods in Enzymology; Expression of recombinant genes in eukaryotic systems. vol. 306. San Diego, CA, USA: Academic Press Inc: London, UK: Academic Press Ltd; 1999. p. 145-53.

38. Rakestraw JA, Sazinsky SL, Piatesi A, Antipov E, Wittrup KD. Directed evolution of a secretory leader for the improved expression of heterologous proteins and full-length antibodies in saccharomyces cerevisiae. Biotechnol Bioeng. 2009;103(6):1192-201.

39. Robinson AS, Hines V, Wittrup KD. Protein disulfide-isomerase overexpression increases secretion of foreign proteins in saccharomyces-cerevisiae. Bio/Technology. 1994;12(4):381-4

40. Gietz RD, Schiestl RH. High-efficiency yeast transformation using the LiAc/SS carrier DNA/PEG method. Nat Protoc. 2007:2(1):31-4.

41. Uzbas F, Sezerman U, Hartl L, Kubicek CP, Seiboth B. A homologous production system for Trichoderma reesei secreted proteins in a cellulasefree background. Appl Microbiol Biotechnol. 2012;93(4):1601-8.
42. Schuster A, Bruno KS, Collett JR, Baker SE, Seiboth B, Kubicek CP, et al. A versatile toolkit for high throughput functional genomics with Trichoderma reesei. Biotechnol Biofuels. 2012;5:1.

43. Nakarisetala T, Penttila M. Production of trichoderma-reesei cellulases on glucose-containing media. Appl Environ Microbiol. 1995;61(10):3650-5.

\section{Submit your next manuscript to BioMed Central and take full advantage of:}

- Convenient online submission

- Thorough peer review

- No space constraints or color figure charges

- Immediate publication on acceptance

- Inclusion in PubMed, CAS, Scopus and Google Scholar

- Research which is freely available for redistribution

Submit your manuscript at www.biomedcentral.com/submit 